\title{
Targeted iron oxide nanoparticles for the enhancement of radiation therapy
}

Anastasia K. Hauser ${ }^{a}$, Mihail I. Mitov ${ }^{\text {b }}$, Emily F. Daley ${ }^{\text {a }}$, Ronald C. McGarry ${ }^{\text {b }}$, Kimberly W. Anderson ${ }^{\text {a }}$, J. Zach Hilt ${ }^{a}$.

${ }^{a}$ Department of Chemical and Materials Engineering, University of Kentucky, Lexington, KY USA 40506

${ }^{b}$ Markey Cancer Center , University of Kentucky, Lexington, KY USA 40506

* Contact Author:

J. Zach Hilt

Professor of Chemical Engineering

Department of Chemical and Materials Engineering

University of Kentucky

177 F. Paul Anderson Tower

Lexington, KY 40506-0046

Tel.: +1-859-257-9844

Fax: +1-859-323-1929

E-Mail: hilt@engr.uky.edu 


\section{Abstract}

To increase the efficacy of radiation, iron oxide nanoparticles can be utilized for their ability to produce reactive oxygen species (ROS). Radiation therapy promotes leakage of electrons from the electron transport chain and leads to an increase in mitochondrial production of the superoxide anion which is converted to hydrogen peroxide by superoxide dismutase. Iron oxide nanoparticles can then catalyze the reaction from hydrogen peroxide to the highly reactive hydroxyl radical. Therefore, the overall aim of this project was to utilize iron oxide nanoparticles conjugated to a cell penetrating peptide, TAT, to escape lysosomal encapsulation after internalization by cancer cells and catalyze hydroxyl radical formation. It was determined that TAT functionalized iron oxide nanoparticles and uncoated iron oxide nanoparticles resulted in permeabilization of the lysosomal membranes. Additionally, mitochondrial integrity was compromised when A549 cells were treated with both TATfunctionalized nanoparticles and radiation. Pre-treatment with TAT-functionalized nanoparticles also significantly increased the ROS generation associated with radiation. A long term viability study showed that TAT-functionalized nanoparticles combined with radiation resulted in a synergistic combination treatment. This is likely due to the TAT-functionalized nanoparticles sensitizing the cells to subsequent radiation therapy, because the nanoparticles alone did not result in significant toxicities.

Keywords: Radiation, cell penetrating peptide, iron oxide nanoparticles, reactive oxygen species, Seahorse mitochondrial stress test 


\section{Introduction}

Iron oxide nanoparticles have been previously studied for their multitude of biological applications, magnetic properties, and lack of protein adsorption after proper coating [1]. Iron oxide nanoparticles have been utilized in magnetically mediated hyperthermia for the treatment of cancer, contrast agents in magnetic resonance imaging, and treatment of anemia [1-4]. However, recent work suggests that inherent toxicities of the nanoparticles can be utilized to enhance current cancer treatments via the generation of reactive oxygen species (ROS) $[5,6]$.

Cancer cells are more susceptible to oxidative insults compared to normal cells due to fast cell proliferation and metabolism so additional ROS stress induced by exogenous agents can overwhelm the relatively low antioxidant capacity and disrupt the redox homeostasis inside cancer cells leading to selective tumor cell toxicity [6-8]. Trachootham et al. transfected T72 cells with the Ras gene and showed that the oncogenic cells containing the Ras gene operated at increased ROS stress compared to the non-transfected cells [8]. This increased oxidative stress caused the T72 Ras cells to be more sensitive to PEITC, an exogenous ROS generating agent. ROS have the ability to result in DNA and lipid damage and disturb signal transduction, which can lead to cell death if the damage is severe enough that it cannot be repaired [9]. Therefore, sensitization of cancer cells to radiation by inducing oxidative stress has the potential to synergistically increase treatment efficacy.

The Haber-Weiss reaction results in the generation of the highly reactive hydroxyl radical from the reaction between super oxide and hydrogen peroxide. This reaction is thermodynamically unfavorable in biologic systems, and with a second order rate constant of zero in aqueous solution, it was found to require a catalyst to proceed [9]. The iron catalyzed Haber-Weiss reaction, which makes use of Fenton chemistry, is now considered the major mechanism by which the highly reactive radical is generated in biological systems [9]. The Fenton chemistry reaction set is shown as Equation 1, and the Haber-Weiss reaction (net reaction) is shown as Equation 2. 


$$
\begin{gathered}
\mathrm{Fe}^{3+}+\mathrm{O}_{2}-\rightarrow \mathrm{Fe}^{2+}+\mathrm{O}_{2} \\
\mathrm{Fe}^{2+}+\mathrm{H}_{2} \mathrm{O}_{2} \rightarrow \mathrm{Fe}^{3+}+\mathrm{OH}-+\mathrm{OH} . \\
\mathrm{O}_{2}-+\mathrm{H}_{2} \mathrm{O}_{2} \rightarrow \mathrm{O}_{2}+\mathrm{OH}-+\mathrm{OH} .
\end{gathered}
$$

Under normal conditions, only trace amounts of iron exist outside of physiologic sinks such as transferrin or ferritin. Proteins sequester iron ions so that the ions circulate bound to transferrin and accumulate within cells in the form of ferritin. The absorption of iron is finely regulated to prevent an excess storage and oxidative attack [10]. Iron oxide nanoparticles have been previously studied for their multitude of biological applications, and recent work suggests that the uptake of iron oxide nanoparticles can lead to a concentration increase of intracellular unbound iron which may result in cell injury or death [11-13], especially when combined with additional therapies $[6,7,11,14]$. When iron oxide nanoparticles are taken up into the cell, they stimulate the generation of ROS via one of two pathways: the release of ions into the cytosol where chelation by citrate or adenosine phosphate takes place resulting in the iron ions participating in the Haber-Weiss cycle or the surface of the iron oxide nanoparticle may act as a catalyst for the Haber-Weiss cycle and the Fenton reaction [11, 15-17]. Both pathways result in the formation of the highly reactive hydroxyl radical. Iron oxide nanoparticles can exist in many forms with two of the most common forms of iron oxide nanoparticles being magnetite $\left(\mathrm{Fe}_{3} \mathrm{O}_{4}\right)$ and maghemite $\left(\mathrm{Fe}_{2} \mathrm{O}_{3}\right)$. It was suggested by Aranda et al. that magnetite nanoparticles would lead to greater ROS formation and oxidative stress due to iron being present as both $\mathrm{Fe}^{3+}$ and $\mathrm{Fe}^{2+}$ ions within magnetite while maghemite has mostly ferric iron ions [18]. Therefore, these studies focus on magnetite iron oxide nanoparticles for the generation of intracellular ROS.

There are multiple pathways within the cell that naturally generate ROS. The pathway of particular interest is mitochondrial respiration which produces the superoxide anion [9]. The superoxide anion is converted to hydrogen peroxide through natural superoxide dismutase, and in the presence of 
iron ions, the conversion of hydrogen peroxide to the highly reactive hydroxyl radical is catalyzed [5]. Although the exact mechanism remains unclear, radiation promotes mitochondrial respiration and therefore increases production of the superoxide anion [19]. Yamamori et al. showed that A549 lung carcinoma exhibited increased oxygen consumption rates as well as increased rates of mitochondrial ROS production at 6 and 12 hours following 5 Gy radiation [20]. Excess ROS is also generated by the mitochondria through electron leakage from the electron transport chain [21]. If the intracellular concentration of the superoxide anion is increased following radiation and iron oxide nanoparticles are present to catalyze hydroxyl radical formation, it is hypothesized that the hydroxyl radical concentration will subsequently be increased, resulting in increased toxicity.

Iron oxide nanoparticles are usually taken up by cells through endocytosis resulting in the nanoparticles being encapsulated in endosomes/lysosomes. Due to the acidic nature of these subcellular compartments, the nanoparticles can be degraded prior to fulfilling their purpose. However, if a cell penetrating peptide (CPP) is conjugated to the surface of the iron oxide nanoparticle, the nanoparticle can avoid receptor mediated endocytosis [22]. In this work, the CPP of particular interest is the TAT peptide (sequence: YGRKKRRQRRR), which contains a characteristic lysine and arginine sequence. Biomolecules with this tag are known to bind to importin $\alpha$ and $\beta$ in the cytoplasm allowing for active transportation to the nuclear pore complex (NPC) and, if small enough, through the NPC into the nucleus [23]. Several studies have utilized the TAT peptide as a cell internalization mechanism [24$28]$ as well as a nuclear targeting moiety [22, 29-32].

Although lysosomes may eventually take up TAT-conjugated nanoparticles residing in the cytosol, the TAT peptide is positively charged and can destabilize lysosomal membranes leading to release of lysosomal contents, including proteolytic enzymes and the nanoparticles [33]. An increase in lysosome membrane permeability is an upstream event in many apoptotic pathways, as the proteolytic enzymes lead to mitochondrial damage by enhancing the production of superoxide radicals and 
hydrogen peroxide, which in turn increases lysosomal membrane permeability, resulting in an amplifying feedback loop [34, 35]. Due to the size of our iron oxide nanoparticles being larger than the upper limit of the nuclear pore complex $(20-70 \mathrm{~nm})$, it was of particular interest to escape endosome/lysosomes in order to interact with other organelles such as the mitochondria [36].

In this study, dextran coated iron oxide nanoparticles were functionalized with the TAT peptide and this nanoparticle system was used to enhance the efficacy of radiation. The TAT peptide increased intracellular concentrations of the nanoparticles compared to uncoated nanoparticles as shown by transmission electron microscopy (TEM). TEM images also indicate that uncoated iron oxide nanoparticles were encapsulated within lysosomes after cell internalization. However, TATfunctionalized nanoparticles were found in the cytoplasm as well as in lysosomes with destabilized membranes. Lysosomal membrane permeability studies confirmed the ability of the TAT peptide to destabilize the lysosomes, and cell respiration studies indicated that TAT-functionalized nanoparticles combined with radiation resulted in a loss of mitochondrial integrity, causing the cells to operate at lower metabolic levels. When combined with radiation, the TAT-functionalized nanoparticles increased reactive oxygen species generation to a greater extent than radiation alone. The combined treatment also resulted in synergistic cytotoxic effects on A549 lung carcinoma, as shown by a long term viability study. Therefore, it has been concluded that TAT-conjugated iron oxide nanoparticles have the ability to destabilize lysosomal membranes, releasing their toxic contents into the cytosol and causing the cells to be more sensitive to radiation therapy. Additionally, after radiation therapy when the mitochondria have increased respiration levels and are producing greater amounts of the superoxide anion, the iron oxide nanoparticles can catalyze the formation of the highly reactive hydroxyl radical. This hypothesis is depicted in Figure 1. 


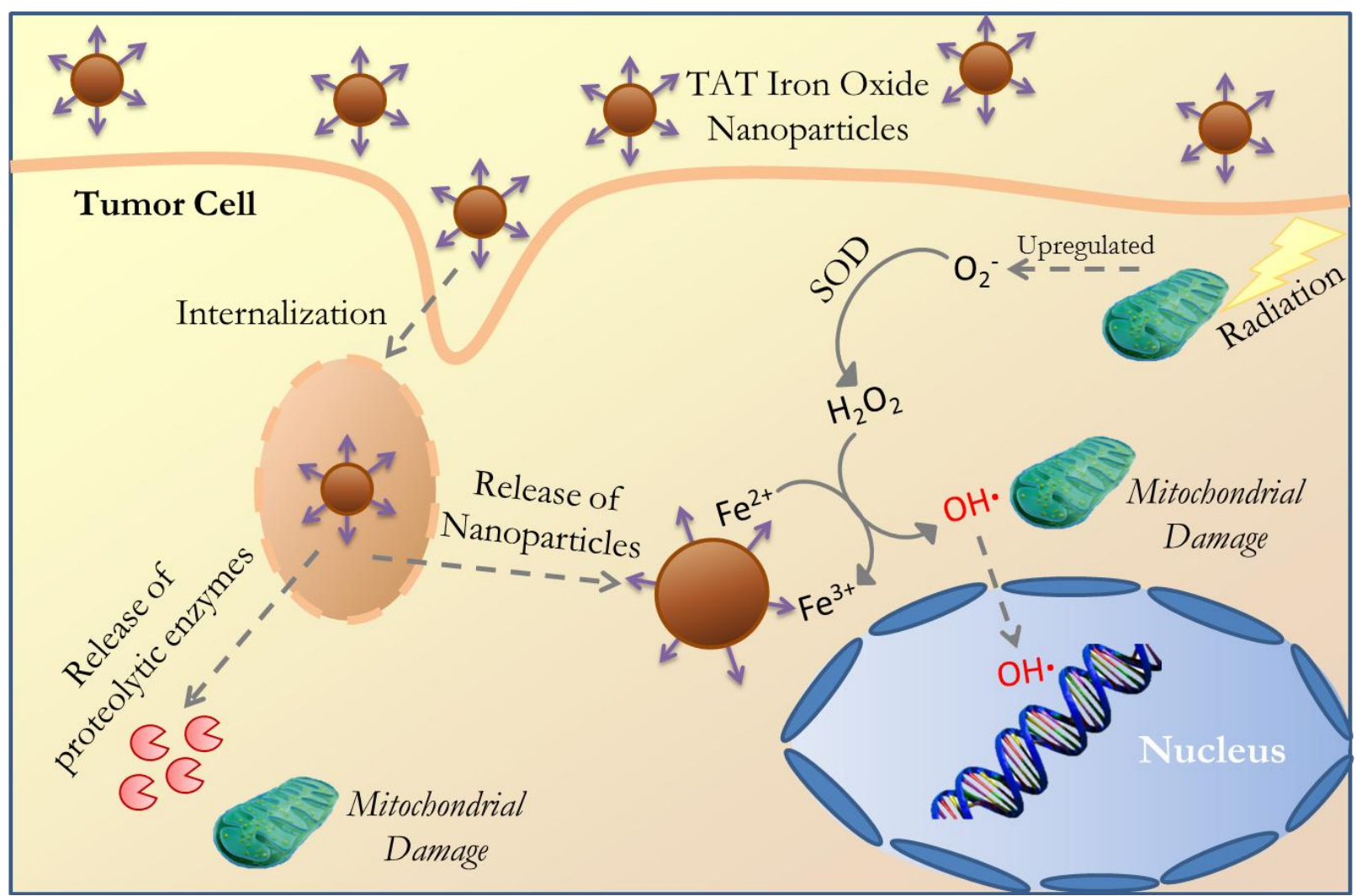

Figure 1. TAT-conjugated iron oxide nanoparticles are internalized into the cell, followed by lysosomal membrane permeabilization. This results in release of proteolytic enzymes as well as the nanoparticles into the cytoplasm where they can interact with organelles such as the nucleus and mitochondria and catalyze the formation of the hydroxyl radical.

\section{Materials and Methods}

\subsection{Materials}

Iron (III) chloride hexahydrate $\left(\mathrm{FeCl}_{3} \cdot 6 \mathrm{H}_{2} \mathrm{O}\right)$, iron (II) chloride $\left(\mathrm{FeCl}_{2} \cdot 4 \mathrm{H}_{2} \mathrm{O}\right), 9-11 \mathrm{kDa}$ dextran, epichlorohydrin $(\mathrm{ECH})$ were obtained from Sigma Aldrich (St. Louis, $\mathrm{MO})$. Ammonium hydroxide $\left(\mathrm{NH}_{4} \mathrm{OH}\right)$ was purchased from EMD Chemicals (Gibbstown, NJ). Phosphate buffered saline solution (PBS) (10X) was purchased from EMD Millipore (Billerica, MA). The activation buffer 2-[N-morpholino] ethane sulfonic acid (MES), N-hydroxysulfosuccinimide (Sulfo-NHS) and 1-ethyl-3- [3-dimethylaminopropyl] carbodiimide hydrochloride (EDC) were purchased from Thermo scientific (Rockford, IL). The TAT peptide was purchased custom from Biomatik. Phosphate buffered saline (PBS), Dulbecco's Modified Eagle Medium (DMEM), pen-strep, L-glutamine, Fungizone ${ }^{\circ}$, sodium pyruvate, and calcein AM were 
obtained from Invitrogen (Frederick, MD). Acridine orange was purchased from Nexcelom Bioscience (Lawrence, MA) and A549 lung carcinoma and trypsin were purchased from American Type Culture Collection (ATCC, Manassas, VA). All materials were used as received.

\subsection{Synthesis of uncoated iron oxide nanoparticles (uncoated $\mathrm{Fe}_{3} \mathrm{O}_{4}$ )}

$\mathrm{FeCl}_{3} \cdot 6 \mathrm{H}_{2} \mathrm{O}$ and $\mathrm{FeCl}_{2} \cdot 4 \mathrm{H}_{2} \mathrm{O}$ were combined in a 2:1 molar ratio (2.2 grams and 0.8 grams, respectively) and dissolved in $60 \mathrm{~mL}$ deionized (DI) water and sealed in a three-neck flask under vigorous stirring and an inert nitrogen environment. The reaction solution was heated to $85{ }^{\circ} \mathrm{C}$ at which $5 \mathrm{ml}$ of $\mathrm{NH}_{4} \mathrm{OH}$ was diluted to $40 \mathrm{~mL}$ with $\mathrm{DI}$ water and the combined solution was injected dropwise into the vessel. The reaction was carried out for 1 hour at $85{ }^{\circ} \mathrm{C}$. The particles were magnetically decanted and washed three times with DI water. The nanoparticles were then re-suspended in DI water and dialyzed against DI water for 24 hours (100 kDa molecular weight cutoff). After dialysis, the nanoparticles were probe sonicated for 10 minutes and then centrifuged at $1000 \mathrm{rpm}$ for 5 minutes to remove large agglomerates.

\subsection{Synthesis of dextran coated iron oxide nanoparticles $\left(\mathrm{Fe}_{3} \mathrm{O}_{4}+\mathrm{Dx}\right)$}

$\mathrm{FeCl}_{3} \cdot 6 \mathrm{H}_{2} \mathrm{O}$ and $\mathrm{FeCl}_{2} \cdot 4 \mathrm{H}_{2} \mathrm{O}$ were combined in a $2: 1$ molar ratio (2.2 grams and 0.8 grams, respectively) and dissolved in $40 \mathrm{~mL}$ deionized (DI) water and sealed in a three-neck flask under vigorous stirring and an inert nitrogen environment. 5 grams of dextran was solubilized in $20 \mathrm{~mL}$ of DI water. The reaction solution was heated to $85{ }^{\circ} \mathrm{C}$ at which $5 \mathrm{ml}$ of $\mathrm{NH}_{4} \mathrm{OH}$ was added to the dextran solution and the combined solution was injected dropwise into the vessel. The reaction was carried out for 1 hour at 85 ${ }^{\circ} \mathrm{C}$. The particles were magnetically decanted and washed three times with DI water. The nanoparticles were then re-suspended in DI water and dialyzed against DI water for 24 hours (100 kDa molecular weight cutoff). After dialysis, the nanoparticles were probe sonicated for 10 minutes and then centrifuged at $1000 \mathrm{rpm}$ for 5 minutes to remove large agglomerates. 


\subsection{Epichlorohydrin (ECH) crosslinking of dextran coated iron oxide nanoparticles $\left(\mathrm{Fe}_{3} \mathrm{O}_{4}+\mathrm{Dx}-\mathrm{ECH}\right)$}

Dextran coated iron oxide nanoparticles were crosslinked using ECH for increased stability [37]. The particle colloid ( $9 \mathrm{~mL}, 1 \mathrm{mmol} F e$ ) was added to $9 \mathrm{~mL} 5 \mathrm{M} \mathrm{NaOH}$ and $1.5 \mathrm{~mL} \mathrm{ECH}$. The reaction was carried out for 24 hours at room temperature under continuous agitation. The particles were then magnetically decanted and dialyzed against DI water (100 kDa molecular weight cutoff) for 24 hours to remove excess $\mathrm{ECH}$.

\subsection{Amine functionalization of crosslinked dextran coated iron oxide nanoparticles $\left(\mathrm{Fe}_{3} \mathrm{O}_{4}+\mathrm{Dx}-\mathrm{ECH}-\right.$} Amine)

An equal volume of ammonium hydroxide to $\mathrm{mmol}$ iron from Fe3O4 + Dx-ECH were combined and placed on the shaker table for 24 hours. After 24 hours, the nanoparticles were dialyzed against DI $\mathrm{H}_{2} \mathrm{O}$ for an additional 24 hours, with their water changed 3 times during this time period.

\subsection{TAT peptide conjugation to iron oxide nanoparticles $\left(\mathrm{Fe}_{3} \mathrm{O}_{4}+\mathrm{TAT}\right)$}

$10 \mathrm{mg}$ of the TAT-peptide was dissolved in $10 \mathrm{~mL}$ MES buffer (2-[N-morpholino] ethane sulfonic acid). 4 mg EDC and $11 \mathrm{mg}$ sulfo-NHS were also added to the solution. Solution was reacted for 15 minutes with continuous agitation after which $14 \mu \mathrm{L}$ of 2- mercaptoethanol was added to the reaction in order to quench excess EDC. Amine-functionalized iron oxide nanoparticles were diluted to $1 \mathrm{mg} \mathrm{Fe}_{3} \mathrm{O}_{4} / \mathrm{mL}$ with PBS. The iron oxide suspension was added to the TAT-peptide solution and reacted over night under continuous agitation. After the $\mathrm{Fe}_{3} \mathrm{O}_{4}+$ TAT reaction was complete, and particles were washed with PBS via magnetic decanting until the washing solution was clear.

\subsection{Iron Concentration Assay}


Between each step of synthesizing a new system of iron oxide nanoparticles, an iron assay was used to determine the iron concentration of the nanoparticles. 20x, 50x, and 100x dilutions of the iron oxide nanoparticles were made in DI water and $10 \mu \mathrm{L}$ of each dilution was added to $10 \mu \mathrm{L} 6 \mathrm{M} \mathrm{HCl}$ and allowed to sit for 3 hours. After this time, $500 \mu \mathrm{L}$ of $1 \mathrm{M}$ acetic acid, $100 \mu \mathrm{L}$ of hydroxylamine hydrochloride, 100 $\mu \mathrm{L}$ of 1,10 phenanthroline, and $280 \mu \mathrm{L}$ of $\mathrm{DI}$ water were added to each dilution. Solutions were left overnight. After 24 hours, the absorbance of each solution $(\lambda=511 \mathrm{~nm})$ was used to calculate the iron concentration based on a standard curve.

\subsection{Cell Culture}

A549 cells were cultured between passages 5-11 in Dulbecco's Modified Eagle Medium (DMEM) supplemented with $10 \%$ of Fetal Bovine Serum (FBS), $1 \mathrm{mM}$ sodium pyruvate, $4 \mathrm{mM}$ L-glutamine, PenStrep (100 $\mu \mathrm{g} / \mathrm{mL}$ penicillin and $100 \mu \mathrm{g} / \mathrm{mL}$ streptomycin), and $10 \mu \mathrm{g} / \mathrm{ml}$ of Fungizone. Cells incubated at $37^{\circ} \mathrm{C}$ and $5 \% \mathrm{CO}_{2}$.

\subsection{Transmission electron microscopy}

A549 cells were seeded into 6 well plates at 13,000 cells $/ \mathrm{cm}^{2}$ and grown for 24 hours. Cells were then exposed to $500 \mu \mathrm{g} / \mathrm{mL}$ iron oxide in cell culture media of either uncoated $\mathrm{Fe}_{3} \mathrm{O}_{4}$ or $\mathrm{Fe}_{3} \mathrm{O}_{4}+$ TAT nanoparticles for 24 hours. After 24 hours, the nanoparticles suspensions were removed and the cells were rinsed with media to remove non-internalized nanoparticles. Half of the samples were then exposed to 5 Gy radiation. After treatment, the cells were washed with PBS to remove media then fixed in $3.5 \%$ glutaraldehyde in $0.1 \mathrm{M}$ Sorenson's buffer for 75 minutes at $4{ }^{\circ} \mathrm{C}$. Cells were then washed 4 times with $0.1 \mathrm{M}$ Sorenson's containing $5 \%$ sucrose, post fixed with $1 \%$ osmium tetraoxide for 45 minutes at $4{ }^{\circ} \mathrm{C}$, then washed again with $0.1 \mathrm{M}$ Sorenson's. Cells were dehydrated in graded ethanols (50-100\%) then absolute ethanol twice at $4{ }^{\circ} \mathrm{C}$. Cells were then embedded in Eponate 12 resin and 
polymerized at $60{ }^{\circ} \mathrm{C}$ prior to slicing and mounting for imaging (Philips BioTwin 12 Transmission Electron Microscope).

\subsection{Acridine orange lysosomal permeabilization experiments}

A549 lung carcinoma cells were seeded at 80,000 cells $/ \mathrm{mL}$ and $2 \mathrm{~mL} /$ well into 6 well plates. Cells were exposed to the nanoparticle systems for three hours at a concentration of $500 \mu \mathrm{g} / \mathrm{mL}$ iron oxide in cell culture media then rinsed to remove any nanoparticles not associated with the cells. Half the cells were exposed to $5 \mathrm{~Gy}$ radiation then the cells were stained with acridine orange $(10 \mu \mathrm{g} / \mathrm{mL})$ for ten minutes at $37^{\circ} \mathrm{C}$ prior to analysis via flow cytometry (FL-3).

\subsection{Mitochondrial stress test}

A549 lung carcinoma cells were seeded at densities of 30,000 per well in Seahorse XF96 microplates and allowed to grow overnight. The cells were then exposed to the iron oxide nanoparticle systems for 3 hours at $500 \mu \mathrm{g} / \mathrm{mL}$ iron oxide in cell culture media then rinsed to remove any nanoparticles not associated with the cells. Half of the samples were then treated with 5 Gy radiation. Mitochondrial stress was then measured using the Seahorse XF 96 Extracellular Flux Analyzer to measure in vitro oxygen consumption rate (OCR) and extracellular acidification rate (ECAR). The bioenergetic baseline profiles can be determined by plotting the ECAR vs OCR signal for the last measurement of base line (or just before adding Oligomycin A to the cells as shown in Figure 2). To expand, cells were incubated for one hour prior to the start of analysis at $37^{\circ} \mathrm{C}$ in XF modified assay medium containing $25 \mathrm{mM}$ Glucose and $1 \mathrm{mM}$ Pyruvate. Three baseline OCR and ECAR values were taken over 16 minutes representing the basal respiration rate, which is the total base line OCR minus the non-mitochondrial respiration. The next three measurements were taken over 20 minutes, after the addition of an ATP synthase inhibitor (Oligomycin 1uM) which helps to calculate the amount of oxygen used for ATP turnover. Next, 
mitochondrial uncoupler, FCCP $(0.6 \mu \mathrm{M})$ was added to force the cells to operate at their maximal respiration rates for 3 measurements over 20 minutes period. Finally, antimycin A and rotenone were added to inhibit the electron transport chain of oxidative phosphorylation and therefore disrupt the formation of the proton gradient across the inner membrane, leading to complete cessation of oxygen consumption by the mitochondria, after which three values were taken in 14 minutes. All measurements were normalized to protein using bicinchoninic acid (BCA) assay. The methods utilized in this study have been previously used to assess the toxicity of drugs and nanoparticles on mitochondria in various cell lines [38-43]. Analysis of the effects of $\mathrm{Fe}_{3} \mathrm{O}_{4}$ nanoparticle systems combined with radiation on each component of the OCR profile can be found in the supplementary information section.

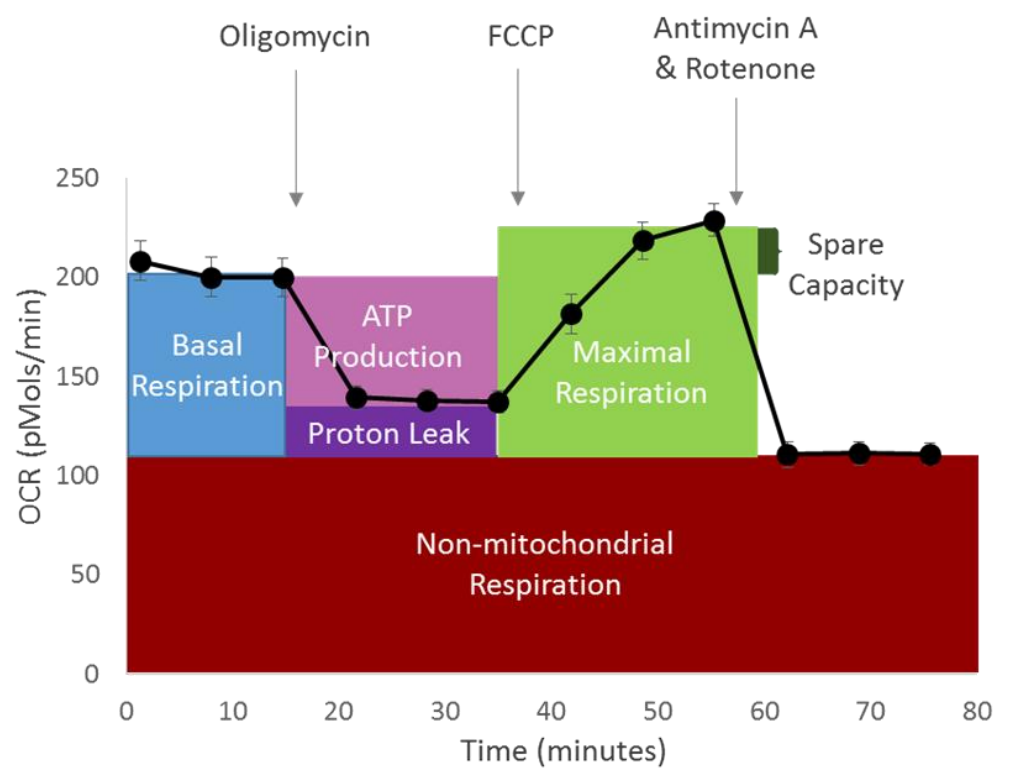

Figure 2. Bioenergetic profile of control A549 cells over time. Error bars represent standard error ( $n=12)$.

\subsection{Reactive Oxygen Species (ROS) Generation}

A549 human lung carcinoma cells were seeded at 40,000 cells $/ \mathrm{mL}$ and $100 \mu \mathrm{L} /$ well in black walled 96 well plates. After 24 hours of growth, the cells were exposed to various iron oxide nanoparticle systems (uncoated, Fe3O4+Dx-ECH, Fe3O4+ Dx-ECH-Amine, or $\mathrm{Fe}_{3} \mathrm{O}_{4}+\mathrm{TAT}$ ) at concentrations of $100 \mu \mathrm{g} / \mathrm{mL}$ or $500 \mu \mathrm{g} / \mathrm{mL}$ iron oxide in cell culture media for 24 hours. After 24 hours of exposure to the iron oxide 
nanoparticle, the nanoparticle solutions were removed and cells were washed 2 times with media, and $100 \mu \mathrm{L}$ of $50 \mu \mathrm{M}$ carboxy-DCF solution was added to each well followed by 20 minutes of incubation to facilitate internalization of the dye. Half of the samples were then irradiated with 5 Gy radiation. Carboxy-DCF fluorescence was measured using a plate reader (ex/em: 485/528 nm) followed by staining with HOESCHT 33342 nuclear stain to normalize data back to the number of cells present.

\subsection{Viability studies}

A549 human lung carcinoma cells were seeded at 5,000 cells $/ \mathrm{mL}$ in black walled 96 well plates. After 24 hours of growth, the cells were exposed to various nanoparticle systems (uncoated, $\mathrm{Fe}_{3} \mathrm{O}_{4}+\mathrm{Dx}-\mathrm{ECH}$, $\mathrm{Fe}_{3} \mathrm{O}_{4}+\mathrm{Dx}-\mathrm{ECH}$-Amine, or $\left.\mathrm{Fe}_{3} \mathrm{O}_{4}+\mathrm{TAT}\right)$ at concentrations of $100 \mu \mathrm{g} / \mathrm{mL}$ or $500 \mu \mathrm{g} / \mathrm{mL}$ iron oxide in cell culture media for 24 hours. After 24 hours of exposure to the nanoparticles, the nanoparticle suspensions were removed and cells were washed 2 times with media and half of the samples were then irradiated with 5 Gy radiation. Cell viability was analyzed 3, 5, and 7 days after treatment using a calcein AM assay. Calcein AM fluorescence was measured on a plate reader and the fluorescence of each treatment was normalized to the fluorescence of the control on that day.

\subsection{Statistical Analysis}

Statistical analysis was completed using SigmaPlot 13.0. A one-way ANOVA was used to determine the statistical differences in the iron oxide nanoparticle viability studies (one each day following treatment). A two-way ANOVA with an interaction term was used to analyze all other experiments.

\section{Results and Discussion}


Iron oxide nanoparticle systems were previously synthesized and characterized for physicochemical properties (Nanomedicine, in press). The final $\mathrm{Fe}_{3} \mathrm{O}_{4}+\mathrm{TAT}$ nanoparticle system had an average hydrodynamic diameter of $127 \mathrm{~nm}$ in DI water and $202 \mathrm{~nm}$ in cell culture media. Individual crystal sizes of approximately 9-12 $\mathrm{nm}$ were previously determined via x-ray diffraction and TEM. Therefore, it is likely that multiple iron oxide crystals are encapsulated within the dextran coating. Attachment of the TAT peptide to the dextran surface was confirmed using zeta potential and FTIR. TEM images of $\mathrm{A} 549$ lung carcinoma after exposure to uncoated $\mathrm{Fe}_{3} \mathrm{O}_{4}$ or $\mathrm{Fe}_{3} \mathrm{O}_{4}+$ TAT with and without 5 Gy radiation treatment are shown in Figure 3. Uncoated $\mathrm{Fe}_{3} \mathrm{O}_{4}$ nanoparticles with and without radiation are localized within lysosomes. No uncoated $\mathrm{Fe}_{3} \mathrm{O}_{4}$ nanoparticles were found to be interacting with the mitochondria, depicted as elongated, striated material in the cytosol, or to have penetrated the nuclear membrane, the darker boundary outlining the nucleus. Uncoated $\mathrm{Fe}_{3} \mathrm{O}_{4}$ nanoparticles are taken up via non-specific endocytosis and do not have the ability to sufficiently destabilize lysosome membranes and escape into the cytosol [33]. Similarly, Könczöl et al. found that uncoated iron oxide nanoparticles were encapsulated in vesicles of A549 lung carcinoma after 24 hours of incubation [5]. There was significantly greater uptake of the $\mathrm{Fe}_{3} \mathrm{O}_{4}+$ TAT nanoparticles into A549 cells as the TAT peptide facilitates cell penetration and escapes receptor mediated endocytosis. $\mathrm{Fe}_{3} \mathrm{O}_{4}+\mathrm{TAT}$ nanoparticles could be found both in lysosomes as well as in the cytosol. The nanoparticles appeared to surround the nuclear membrane, but they did not penetrate it due to size restraints of the nuclear pore complex [36]. When combined with radiation, the $\mathrm{Fe}_{3} \mathrm{O}_{4}+\mathrm{TAT}$ nanoparticles appeared to destabilize the lysosomal membranes even more and greater interaction with surrounding mitochondria was observed. Similar lysosomal escape into the cytosol by nanoparticles conjugated with a cell penetrating peptide or nuclear localizing signal, such as TAT, has been previously observed $[23,31]$. 

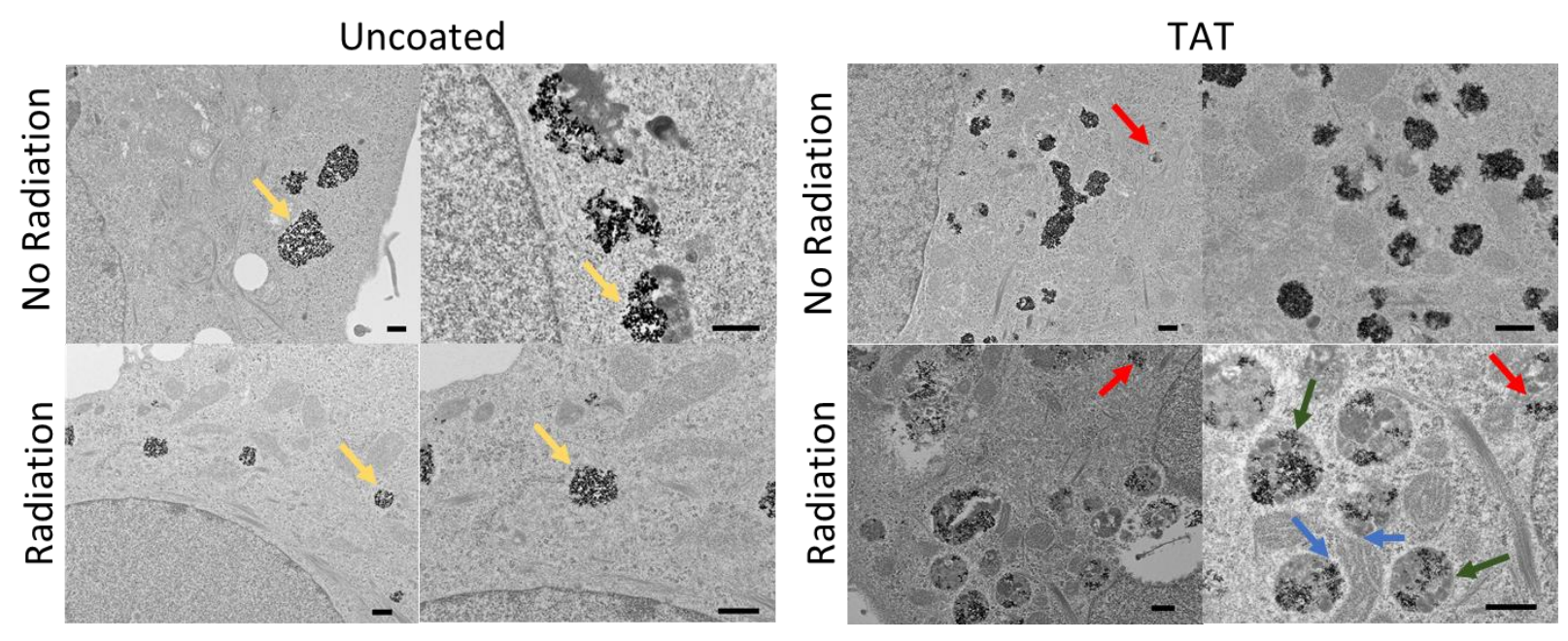

Figure 3. Internalization of uncoated or TAT-conjugated iron oxide nanoparticles by A549 lung carcinoma, with and without radiation treatment. Scale bars represent $200 \mathrm{~nm}$. Yellow arrows indicate nanoparticles encapsulated within lysosomes, red arrows indicate nanoparticles residing in the cytosol, blue arrows point to nanoparticle-mitochondria interaction, and green arrows indicate lysosomal destabilization.

Lysosomal membrane permeabilization is an upstream event in many apoptosis pathways as destabilization of the lysosomal membranes releases lysosomal contents such as proteolytic enzymes (cathepsins, etc.) into the cytosol, which then induce mitochondrial damage by enhancing the production of superoxide radicals and hydrogen peroxide, further increasing lysosome permeability, resulting in an amplifying feedback loop [34]. Acridine Orange (AO) is a metachromatic fluorophore which gives a distinct red fluorescence at high lysosomal concentrations and a weakly green fluorescence at low cytosolic concentrations and can therefore be used to measure lysosomal membrane permeability, with a decrease in the red fluorescence channel corresponding to an increase in lysosome permeability [33]. This method was used by Domenech et al. to prove that targeted iron oxide nanoparticles have the ability to disrupt lysosomal membranes via mechanical forces actuated by an alternating magnetic field [44]. Therefore, AO was used to quantify lysosomal permeabilization by the $\mathrm{Fe}_{3} \mathrm{O}_{4}$ nanoparticle systems with and without radiation. As shown in Figure 4, uncoated $\mathrm{Fe}_{3} \mathrm{O}_{4}$ and $\mathrm{Fe}_{3} \mathrm{O}_{4}+\mathrm{TAT}$ nanoparticles significantly decreased $\mathrm{AO}$ fluorescence compared to the control, but no further decrease was observed with the addition of radiation. Hydrogen peroxide was used as a positive 
control and there was no difference between hydrogen peroxide treatment and $\mathrm{Fe}_{3} \mathrm{O}_{4}+$ TAT nanoparticles indicating lysosomal membrane permeabilization. As previously shown, the TAT peptide on the nanoparticle surface destabilizes lysosomal membranes due to its highly positive charge [45]. Uncoated $\mathrm{Fe}_{3} \mathrm{O}_{4}$ nanoparticles can catalyze the formation of the hydroxyl radical inside the lysosomes leading to slight lysosome membrane destabilization $[5,35,46]$ and therefore a minor, but statistically significant, decrease in $\mathrm{AO}$ fluorescence. Both $\mathrm{Fe}_{3} \mathrm{O}_{4}+\mathrm{Dx}-\mathrm{ECH}$ and $\mathrm{Fe}_{3} \mathrm{O}_{4}+\mathrm{Dx}-\mathrm{ECH}-\mathrm{Amine}$ nanoparticles have protective coatings on their surfaces preventing the formation of ROS by surface reaction, which explains why these systems do not result in lysosomal membrane permeabilization.

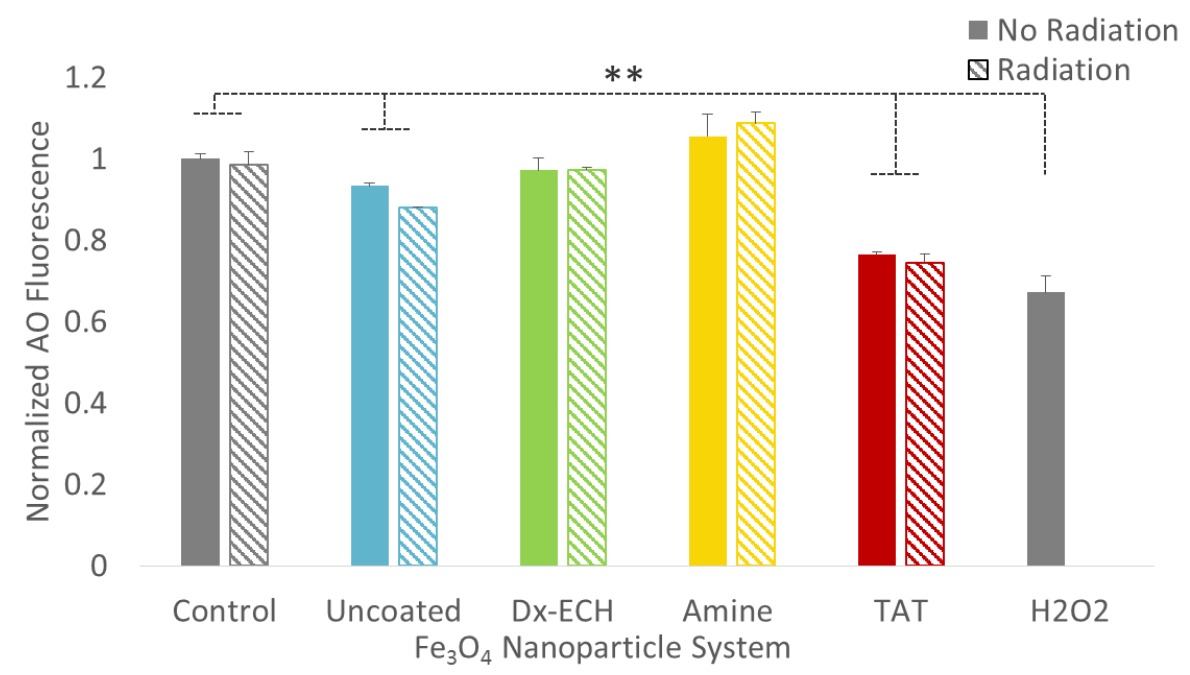

Figure 4. Normalized acridine orange (AO) fluorescence of A549 lung carcinoma after 2 hour treatment with $\mathrm{Fe}_{3} \mathrm{O}_{4}$ nanoparticle systems with and without radiation. Error bars represent standard error $(n=3)$ and ${ }^{* *}$ indicates a significant difference from the control $(p<0.01)$ via a two-way ANOVA.

As previously mentioned, lysosomal permeability and toxicity of iron oxide nanoparticles can lead to toxic mitochondrial effects. The effects of the combined $\mathrm{Fe}_{3} \mathrm{O}_{4}$ nanoparticle treatments with radiation on mitochondrial function were analyzed using a XF96 Seahorse instrument, which measures oxygen consumption rate (OCR) and extracellular acidification rate (ECAR) over time. Figure 5 represents the basal respiration associated with $\mathrm{A} 549$ lung carcinoma cells following $\mathrm{Fe}_{3} \mathrm{O}_{4}$ nanoparticle treatment with and without $5 \mathrm{~Gy}$ radiation treatment. Control $\mathrm{A} 549$ cells, which had not been exposed to $\mathrm{Fe}_{3} \mathrm{O}_{4}$ nanoparticles, had significantly increased basal respiration rates after radiation treatment, which is 
consistent with previous studies [20]. Uncoated $\mathrm{Fe}_{3} \mathrm{O}_{4}$ and $\mathrm{Fe}_{3} \mathrm{O}_{4}+$ TAT nanoparticles significantly decreased basal respiration rates when combined with radiation compared to radiation alone and no increase in respiration was observed following radiation treatment, indicating that mitochondrial integrity was compromised by the presence of the nanoparticles. Figure 6 represents the maximal respiration levels associated with $\mathrm{A} 549$ lung carcinoma cells following $\mathrm{Fe}_{3} \mathrm{O}_{4}$ nanoparticle treatment with and without radiation. At the maximal respiration levels, there was a significant interaction between the nanoparticle system and radiation, indicating that the effects of the nanoparticle system were dependent on radiation exposure. An increase in respiration rate after radiation treatment was observed in both the control and $\mathrm{Fe}_{3} \mathrm{O}_{4}+\mathrm{Dx}-\mathrm{ECH}-\mathrm{Amine}$ nanoparticles. Additionally, the nanoparticle systems decreased the maximal respiration of the cells compared to the control, both with and without radiation treatment, indicating that the nanoparticles compromised the integrity of the mitochondria. Mitochondrial DNA is highly susceptible to damage by ROS and other agents because it is not as well protected by histones as is nuclear DNA [47]. Therefore, additional ROS stress by the uncoated $\mathrm{Fe}_{3} \mathrm{O}_{4}$ nanoparticles, or ROS stress induced by release of lysosomal contents, can lead to significant toxicities to the mitochondria.

The overall metabolism of the cells can be depicted by plotting OCR versus ECAR. Figure 7 represents the metabolic energy associated with $\mathrm{A} 549$ lung carcinoma cells after treatment with $\mathrm{Fe}_{3} \mathrm{O}_{4}$ nanoparticle systems with and without radiation and after FCCP stimulation so the cells were operating at their total maximal respiration levels. All cells treated with the $\mathrm{Fe}_{3} \mathrm{O}_{4}$ nanoparticle systems only were operating at approximately the same ECAR levels but decreased OCR compared to the control. The initial decrease in OCR associated with $\mathrm{Fe}_{3} \mathrm{O}_{4}+$ TAT nanoparticle treatment suggests that these nanoparticles can sensitize the cells to subsequent radiation therapy. The cells treated with both the $\mathrm{Fe}_{3} \mathrm{O}_{4}+\mathrm{TAT}$ nanoparticles and radiation operated at a significantly lower energy level than cells treated with nanoparticles alone. This is an indication that cells treated with $\mathrm{Fe}_{3} \mathrm{O}_{4}+$ TAT nanoparticles and 
radiation do not have the ability to respond to external stimuli, such as FCCP, indicating a decrease in substrate availability or that mitochondrial mass or integrity has been compromised $[42,48]$. Previous studies have shown that various iron oxide nanoparticle systems can adversely affect mitochondrial integrity. Khan et al. evaluated the effects of iron oxide nanoparticle concentration on the mitochondrial membrane potential (MMP) of HeLa cells and found that, with increasing nanoparticle concentration, the percentage of cells with loss of MMP increased as well [49].

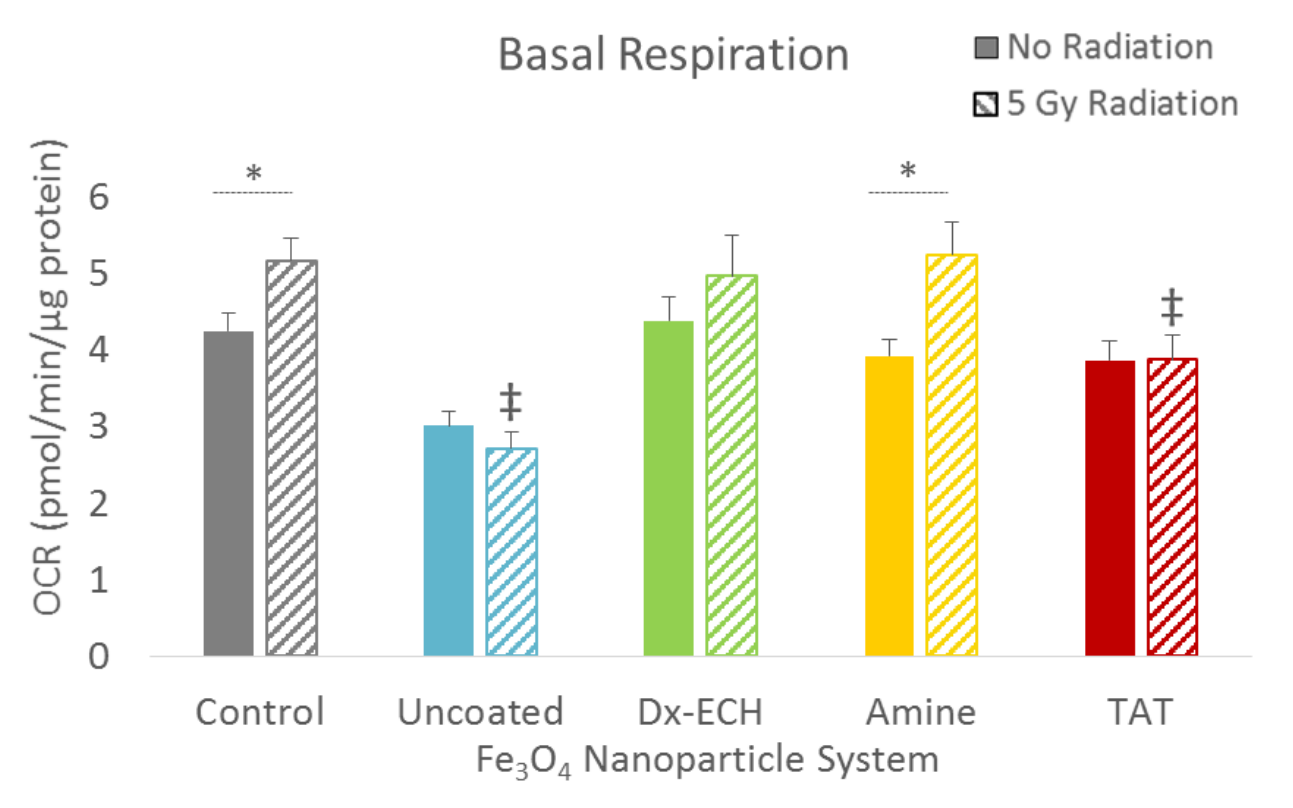

Figure 5. Basal oxygen consumption rates of $\mathrm{A} 549$ lung carcinoma cells after $\mathrm{Fe}_{3} \mathrm{O}_{4}$ nanoparticle treatment with and without radiation. Error bars represent standard error $(n=12) .{ }^{*}$ indicates a significant difference between the no radiation and radiation treatments within a nanoparticle system $(p<0.05),+$ indicates a significant difference compared to the control without radiation $(p<0.05)$ and $\ddagger$ indicates a significant difference from the control with radiation $(p<0.05)$, via a two-way ANOVA with an interaction term. 


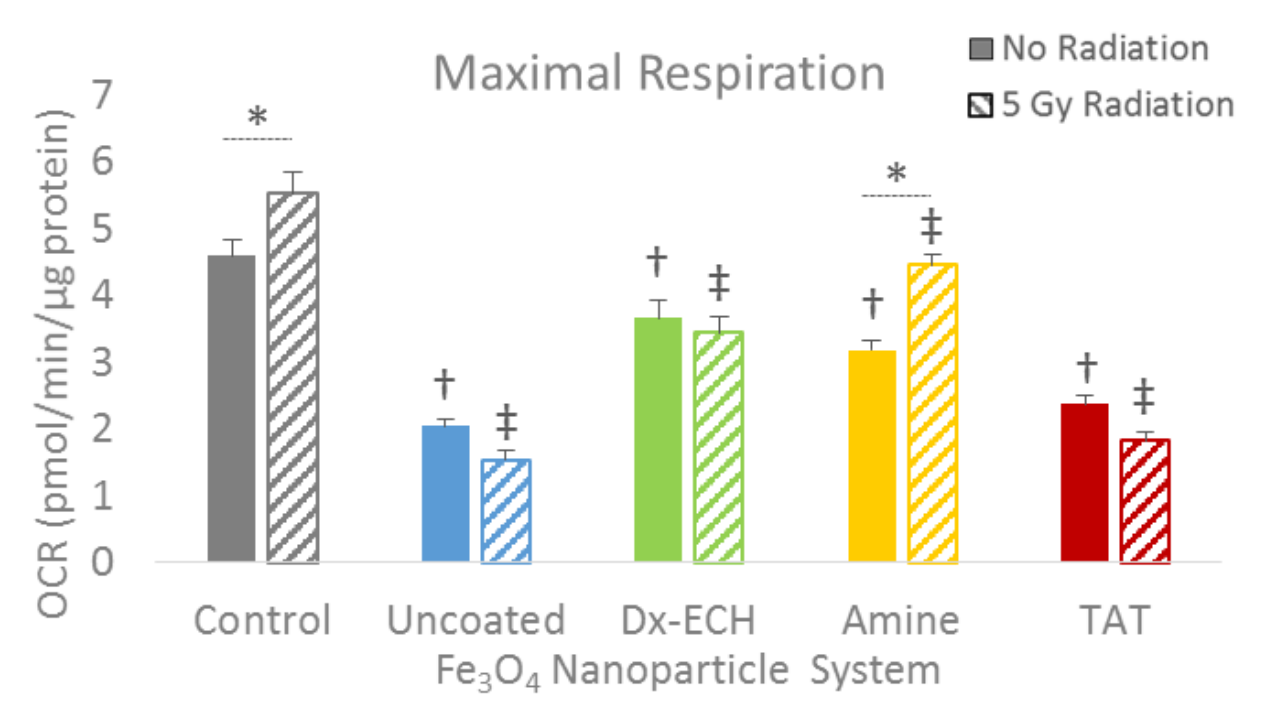

Figure 6. Maximal oxygen consumption rates of $\mathrm{A} 549$ lung carcinoma cells after $\mathrm{Fe}_{3} \mathrm{O}_{4}$ nanoparticle treatment with and without radiation. Error bars represent standard error $(n=12) . *$ indicates a significant difference between the no radiation and radiation treatments within a nanoparticle system $(p<0.05),+$ indicates a significant difference compared to the control without radiation $(p<0.05)$ and $\ddagger$ indicates a significant difference from the control with radiation $(p<0.05)$, via a two-way ANOVA with an interaction term.

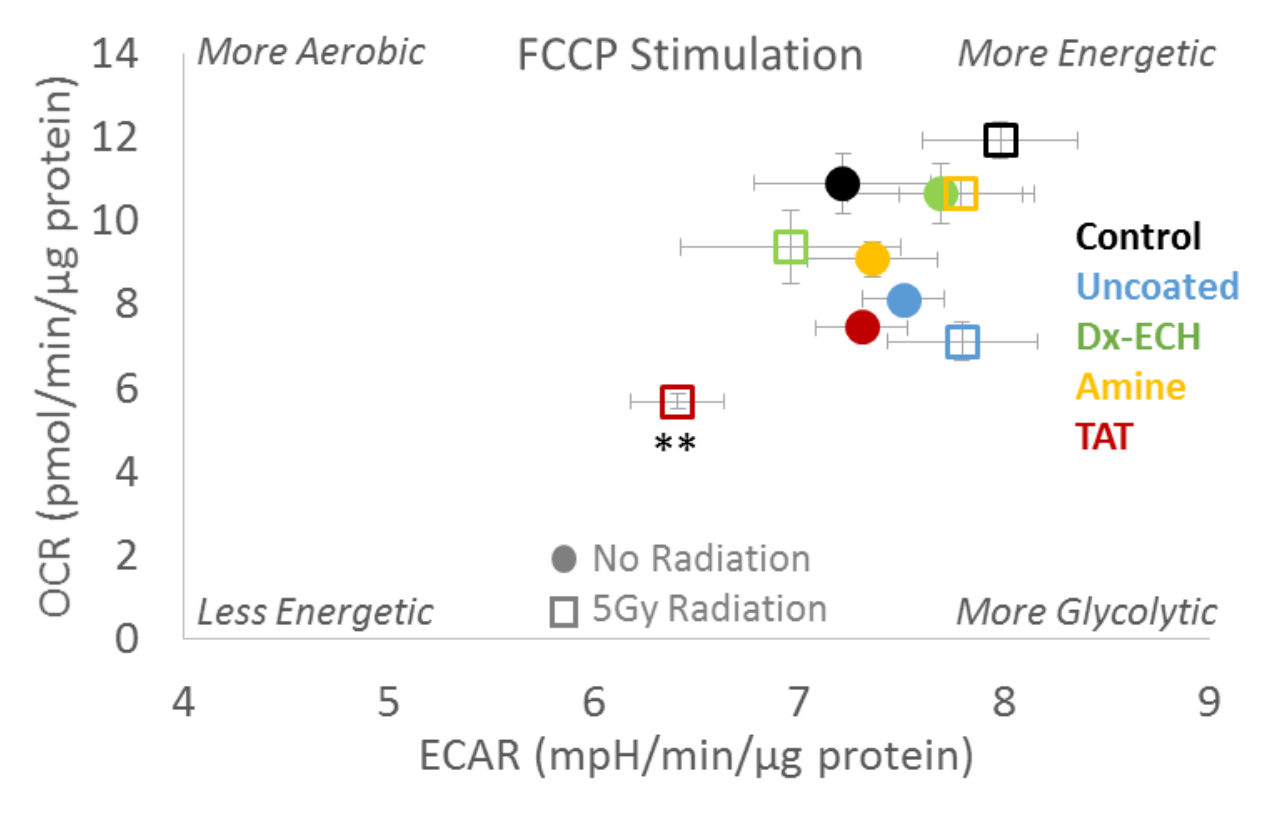

Figure 7. Oxygen consumption rate vs. extracellular acidification rate of A549 lung carcinoma after exposure to $\mathrm{Fe}_{3} \mathrm{O}_{4}$ nanoparticle systems with and without radiation and FCCP stimulation. Error bars represent standard error $(n=12)$ and $* *$ indicates a significant difference in both OCR and ECAR from noradiation $\mathrm{Fe}_{3} \mathrm{O}_{4}$ nanoparticle.

Cancer cells are highly sensitive to exogenous ROS inducing agents due to increased inherent ROS production being associated with oncogenic transformation making the cells highly dependent 
upon their antioxidant systems [6, 7]. Therefore, the ROS production associated with the nanoparticle systems with and without radiation was analyzed. As shown in Figure 8, ionizing radiation treatment alone significantly increased ROS production in A549 lung carcinoma, and this was further increased by pre-treatment with uncoated $\mathrm{Fe}_{3} \mathrm{O}_{4}, \mathrm{Fe}_{3} \mathrm{O}_{4}+\mathrm{Dx}-\mathrm{ECH}$-Amine and $\mathrm{Fe}_{3} \mathrm{O}_{4}+\mathrm{TAT}$ at a concentration of 500 $\mu \mathrm{g} / \mathrm{mL}$. Additionally, the $\mathrm{Fe}_{3} \mathrm{O}_{4}+\mathrm{TAT}$ increased ROS generation to a significantly greater extent than the other systems. It is hypothesized that uncoated $\mathrm{Fe}_{3} \mathrm{O}_{4}$ nanoparticles increase ROS by surface catalysis of the hydroxyl radical which is the main form of ROS measured by carboxy-DCF $[5,50]$. Significant work has been completed to link oxidative stress induced by uncoated iron oxide nanoparticles to nanoparticle toxicity $[6,13,51-53]$. Ahamed et al. and Khan et al. both showed that uncoated iron oxide nanoparticles induced oxidative stress in A549 lung carcinoma, which increased with increasing concentration and increasing exposure time $[49,54]$. The positive charge associated with primary amines functionalized to the nanoparticle surface could slightly increase lysosomal permeability, although this was not observed in the AO studies, resulting in the release of some lysosomal contents and inducing ROS associated toxicities. $\mathrm{Fe}_{3} \mathrm{O}_{4}+\mathrm{TAT}$ nanoparticles destabilized lysosomal membranes and facilitated release of toxic components, as well as the nanoparticles, which compromised mitochondrial integrity and increased ROS production. Therefore, ROS generation was significantly increased when radiation was combined with the $\mathrm{Fe}_{3} \mathrm{O}_{4}+\mathrm{TAT}$ nanoparticles. 


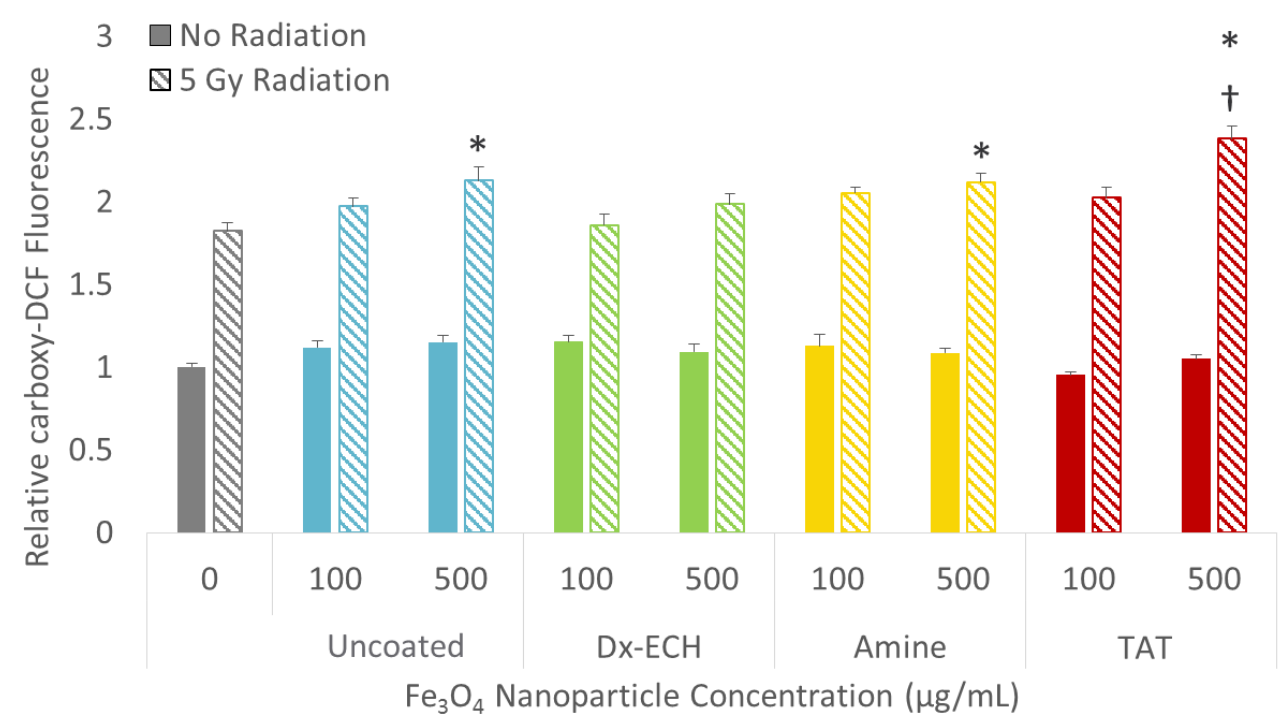

Figure 8. Relative carboxy-DCF fluorescence in A549 lung carcinoma following 24 hour treatment with $\mathrm{Fe}_{3} \mathrm{O}_{4}$ nanoparticle systems with and without $5 \mathrm{~Gy}$ radiation treatment. Error bars represent standard error $(n=12)$ and * indicates a significant difference compared to radiation alone and + indicates a significant difference compared to $500 \mu \mathrm{g} / \mathrm{mL}$ uncoated and $500 \mu \mathrm{g} / \mathrm{mL}$ amine functionalized $\mathrm{Fe}_{3} \mathrm{O}_{4}$ nanoparticles.

To determine whether the nanoparticle systems combined with radiation treatment had an effect on cell viability, a long term viability study was completed. A549 cells were treated for 24 hours with the nanoparticle systems to facilitate uptake, followed by treatment with 5 Gy radiation. Cells were then re-seeded and allowed to grow for 3, 5 or 7 days post treatment. Figure 9 displays the relative viability of $\mathrm{A} 549$ lung carcinoma 3, 5 and 7 days post treatment with $\mathrm{Fe}_{3} \mathrm{O}_{4}$ nanoparticles alone, radiation alone, and the combined treatment. When combined with radiation, uncoated $\mathrm{Fe}_{3} \mathrm{O}_{4}$ nanoparticles resulted in a delayed effect, as only at day 7 was the combined treatment significantly different from radiation alone. The uncoated $\mathrm{Fe}_{3} \mathrm{O}_{4}$ nanoparticles increased lysosomal permeability and increased intracellular ROS production, but the toxic effects were delayed. The $\mathrm{Fe}_{3} \mathrm{O}_{4}+\mathrm{Dx}-\mathrm{ECH}$ nanoparticles did not significantly enhance the efficacy of radiation treatment. This was expected as this nanoparticle system did not induce lysosomal permeabilization, decrease mitochondrial integrity, nor increase ROS generation. The $\mathrm{Fe}_{3} \mathrm{O}_{4}+\mathrm{Dx}-\mathrm{ECH}-\mathrm{Amine}$ nanoparticles did increase the efficacy of radiation treatment in the short term, but the effects did not continue through the analysis times. This could be due to the 
$\mathrm{Fe}_{3} \mathrm{O}_{4}+\mathrm{Dx}-\mathrm{ECH}-\mathrm{Amine}$ nanoparticles having the ability to increase ROS generation upon exposure to radiation, but the nanoparticles did not cause other cellular effects. Therefore, the slight increase in ROS when combined with radiation by the $\mathrm{Fe}_{3} \mathrm{O}_{4}+\mathrm{Dx}-\mathrm{ECH}$-Amine nanoparticles was enough to induce increased toxicities in short time frames, but as the cells continued to grow for the longer time points, they were able to overcome the toxicities induced by the slight increases in exogenous $\mathrm{ROS} \mathrm{Fe}_{3} \mathrm{O}_{4}+\mathrm{TAT}$ nanoparticles significantly enhanced the effect of radiation when cell viability was analyzed 3, 5 and 7 days post treatment, indicating that the $\mathrm{Fe}_{3} \mathrm{O}_{4}+$ TAT nanoparticles successfully sensitized A549 lung carcinoma to radiation therapy. $\mathrm{Fe}_{3} \mathrm{O}_{4}+$ TAT nanoparticles increased lysosomal membrane permeabilization, releasing toxic contents into the cytosol, which then compromised mitochondrial integrity and sensitized the cells to radiation treatment. The efficacy of the combined treatment was analyzed using a set of equations established by Ito et al. [55] and previously used by Babincova et al. [56]. These equations are displayed in Table 1 , and the calculations for the $\mathrm{Fe}_{3} \mathrm{O}_{4}+\mathrm{TAT}$ nanoparticles are shown in Table 2. On each day of analysis following treatment, the combined treatment of $\mathrm{Fe}_{3} \mathrm{O}_{4}+\mathrm{TAT}$ nanoparticles and radiation therapy on A549 lung carcinoma was significantly greater than the expected outcome of combining the two treatments, indicating that it was a synergistic treatment. It should be noted that $\mathrm{Fe}_{3} \mathrm{O}_{4}+\mathrm{Dx}-\mathrm{ECH}-\mathrm{Amine}$ nanoparticles combined with radiation resulted in a synergistic effect three days after treatment, but the effects were not sustained for longer time periods. Additionally, uncoated $\mathrm{Fe}_{3} \mathrm{O}_{4}$ nanoparticles combined with radiation significantly reduced $\mathrm{A} 549$ viability seven days post treatment compared to the individual treatments, but this combined treatment resulted in an additive effect rather than synergistic. $\mathrm{Fe}_{3} \mathrm{O}_{4}+\mathrm{TAT}$ nanoparticle treatment combined with radiation is the only combination treatment which resulted in synergistic effects at all time points analyzed. 

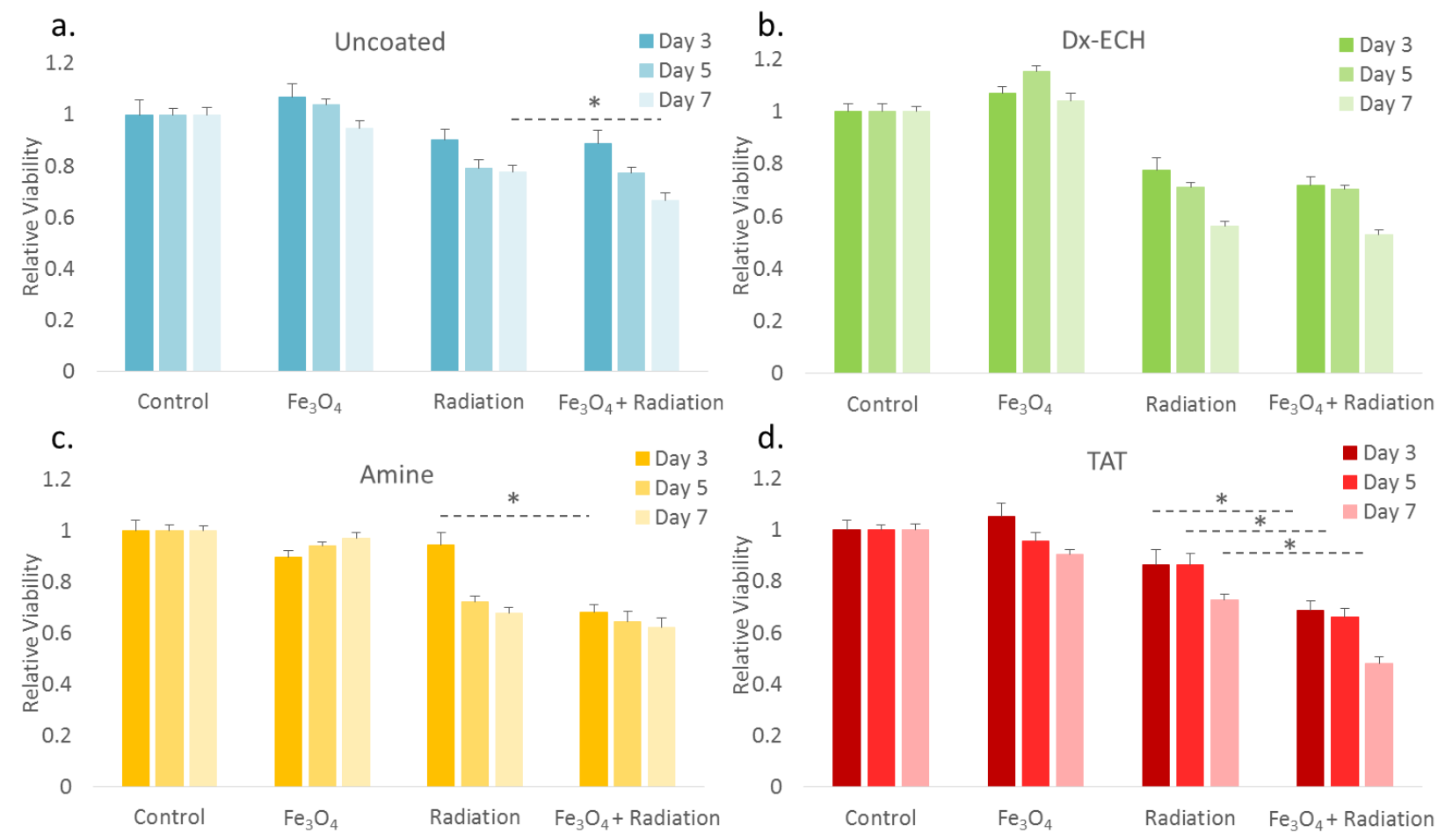

Radiation $\quad \mathrm{Fe}_{3} \mathrm{O}_{4}+$ Radiation

Figure 9. Relative viability of A549 lung carcinoma 3, 5 or 7 days following a) uncoated b) Dx-ECH c) amine functionalized or d) TAT-conjugated $\mathrm{Fe}_{3} \mathrm{O}_{4}$ nanoparticle treatment with and without $5 \mathrm{~Gy}$ radiation. Error bars represent standard error $(n=12)$ and * indicates a significant difference $(p<0.05)$ via a one-way ANOVA.

Table 1. Equations developed for analysis of combinational treatments [55, 56].

Synergistic: $\quad\left[\mathrm{Fe}_{3} \mathrm{O}_{4}+\mathrm{TAT}+\right.$ Radiation $]<\left[\mathrm{Fe}_{3} \mathrm{O}_{4}+\mathrm{TAT}\right] \times[$ Radiation $] / 100$

Additive: $\quad\left[\mathrm{Fe}_{3} \mathrm{O}_{4}+\mathrm{TAT}+\right.$ Radiation $]=\left[\mathrm{Fe}_{3} \mathrm{O}_{4}+\mathrm{TAT}\right] \times[$ Radiation $] / 100$

Sub-additive: $\left[\mathrm{Fe}_{3} \mathrm{O}_{4}+\mathrm{TAT}\right] \times[$ Radiation $] / 100<\left[\mathrm{Fe}_{3} \mathrm{O}_{4}+\mathrm{TAT}+\right.$ Radiation $]<\left[\mathrm{Fe}_{3} \mathrm{O}_{4}+\mathrm{TAT}\right]$; if $\left[\mathrm{Fe}_{3} \mathrm{O}_{4}+\mathrm{TAT}\right]<[$ Radiation]

Interference: $\left[\mathrm{Fe}_{3} \mathrm{O}_{4}+\mathrm{TAT}\right]<\left[\mathrm{Fe}_{3} \mathrm{O}_{4}+\mathrm{TAT}+\right.$ Radiation $]<$ [Radiation], if $\left[\mathrm{Fe}_{3} \mathrm{O}_{4}+\mathrm{TAT}\right]<$ [Radiation]

Antagonistic: [Radiation] $<\left[\mathrm{Fe}_{3} \mathrm{O}_{4}+\mathrm{TAT}+\right.$ Radiation], if $\left[\mathrm{Fe}_{3} \mathrm{O}_{4}+\mathrm{TAT}\right]<$ [Radiation]

Table 2. Calculations to analyze the effects of combined $\mathrm{Fe}_{3} \mathrm{O}_{4}+\mathrm{TAT}$ nanoparticles and radiation treatments. Values represent average percent viability \pm standard error $(n=12)$ on days 3,5 and 7 post treatment. $*(p<0.05)$ and ${ }^{* *}(p<0.01)$ indicate a significant difference from the $\left[\mathrm{Fe}_{3} \mathrm{O}_{4}+\right.$ TAT]x[Radiation]/100 group on the same day.

\begin{tabular}{lcccc}
\hline & $\mathrm{Fe}_{3} \mathrm{O}_{4}+\mathrm{TAT}$ & Radiation & {$\left[\mathrm{Fe}_{3} \mathrm{O}_{4}+\mathrm{TAT}\right] \mathbf{\mathrm { T }}[\mathrm{Radiation}] / \mathbf{1 0 0}$} & {$\left[\mathrm{Fe}_{3} \mathrm{O}_{4}+\mathrm{TAT}+\mathrm{Radiation}\right]$} \\
Day 3 & $105.4 \pm 4.5$ & $86.4 \pm 6.1$ & $92.5 \pm 9.2$ & $68.7 \pm 3.6^{*}$ \\
Day 5 & $95.6 \pm 3.2$ & $86.4 \pm 4.6$ & $81.8 \pm 3.8$ & $66.2 \pm 3.4 * *$ \\
Day 7 & $90.4 \pm 2.0$ & $72.6 \pm 2.6$ & $65.5 \pm 2.4$ & $48.0 \pm 2.6^{* *}$ \\
\hline
\end{tabular}




\section{Conclusions}

The cell penetrating peptide, TAT, was successfully conjugated to dextran-coated iron oxide nanoparticles. Electron microscopy of A549 lung carcinoma after uptake of $\mathrm{Fe}_{3} \mathrm{O}_{4}+$ TAT nanoparticles showed the nanoparticles interacting with mitochondria and membrane destabilization of lysosomes containing $\mathrm{Fe}_{3} \mathrm{O}_{4}+$ TAT nanoparticles. Lysosomal permeability was confirmed and quantified using the AO assay. Both the uncoated $\mathrm{Fe}_{3} \mathrm{O}_{4}$ and $\mathrm{Fe}_{3} \mathrm{O}_{4}+$ TAT nanoparticles had the ability to permeabilize lysosomal membranes after cellular uptake due to ROS generation and the positive charge of the TAT peptide, respectively. $\mathrm{Fe}_{3} \mathrm{O}_{4}+$ TAT nanoparticles combined with radiation also affected mitochondrial integrity of the cells. When mitochondria were uncoupled with FCCP, cells that had been previously treated with $\mathrm{Fe}_{3} \mathrm{O}_{4}+$ TAT nanoparticles combined with radiation showed significantly lower capability to meet ATP demands than the nanoparticle only treatment, indicating a loss of metabolic potential. ROS generation was also predicted to play a role in the additional toxicities associated with radiation when the cells were pre-treated with the nanoparticle systems. When combined with radiation, uncoated $\mathrm{Fe}_{3} \mathrm{O}_{4}, \mathrm{Fe}_{3} \mathrm{O}_{4}+\mathrm{Dx}-\mathrm{ECH}$-Amine, and $\mathrm{Fe}_{3} \mathrm{O}_{4}+$ TAT nanoparticles significantly increased ROS production compared to radiation alone in A549 lung carcinoma. Due to this increase in ROS generation, in Iysosomal permeability, and the loss of mitochondrial integrity and function, the combined treatment of $\mathrm{Fe}_{3} \mathrm{O}_{4}+\mathrm{TAT}$ nanoparticles and radiation resulted in a synergistic decrease in cell viability.

\section{Acknowledgments}

This research was supported by the Redox Metabolism Shared Resource of the University of Kentucky Markey Cancer Center (P30CA177558). The project described was partially supported by Grant Number R25CA153954 from the National Cancer Institute. The content is solely the responsibility of the authors and does not necessarily represent the official views of the National Cancer Institute or the 
National Institutes of Health. Additionally, this work was supported by the National Science Foundation Graduate Research Fellowship Program Grant No. DGE-1247392. Any opinions, findings, and conclusions or recommendations expressed in this material are those of the author(s) and do not necessarily reflect the views of the National Science Foundation.

\section{References}

[1] Laurent S, Dutz S, Hafeli UO, Mahmoudi M. Magnetic fluid hyperthermia: Focus on superparamagnetic iron oxide nanoparticles. Advances in Colloid and Interface Science. 2011;166:8-23.

[2] McCormack PL. Ferumoxytol In Iron Deficiency Anaemia in Adults With Chronic Kidney Disease. Drugs. 2012;72:2013-22.

[3] Hu R, Ma S, Li H, Ke X, Wang G, Wei D, et al. Effect of magnetic fluid hyperthermia on lung cancer nodules in a murine model. Oncology Letters. 2011;2:1161-4.

[4] Dennis CL, Jackson AJ, Borchers JA, Hoopes PJ, Strawbridge R, Foreman AR, et al. Nearly complete regression of tumors via collective behavior of magnetic nanoparticles in hyperthermia. Nanotechnology. 2009;20:395103.

[5] Koenczoel M, Weiss A, Stangenberg E, Gminski R, Garcia-Kaeufer M, Giere R, et al. Cell-Cycle Changes and Oxidative Stress Response to Magnetite in A549 Human Lung Cells. Chemical Research in Toxicology. 2013;26:693-702.

[6] Luo C, Li Y, Yang L, Wang X, Long J, Liu J. Superparamagnetic iron oxide nanoparticles exacerbate the risks of reactive oxygen species-mediated external stresses. Archives of Toxicology. 2015;89:357-69.

[7] Huang G, Chen HB, Dong Y, Luo XQ, Yu HJ, Moore Z, et al. Superparamagnetic Iron Oxide Nanoparticles: Amplifying ROS Stress to Improve Anticancer Drug Efficacy. Theranostics. 2013;3:116-26.

[8] Trachootham D, Zhou $Y$, Zhang $H$, Demizu $Y$, Chen Z, Pelicano $H$, et al. Selective killing of oncogenically transformed cells through a ROS-mediated mechanism by beta-phenylethyl isothiocyanate. Cancer Cell. 2006;10:241-52.

[9] Kehrer JP. The Haber-Weiss reaction and mechanisms of toxicity. Toxicology. 2000;149:43-50.

[10] Emerit J, Beaumont C, Trivin F. Iron metabolism, free radicals, and oxidative injury. Biomedicine \& Pharmacotherapy. 2001;55:333-9.

[11] Klein S, Sommer A, Distel LVR, Neuhuber W, Kryschi C. Superparamagnetic iron oxide nanoparticles as radiosensitizer via enhanced reactive oxygen species formation. Biochemical and Biophysical Research Communications. 2012;425:393-7.

[12] Weissleder R, Stark DD, Engelstad BL, Bacon BR, Compton CC, White DL, et al. SUPERPARAMAGNETIC IRON-OXIDE - PHARMACOKINETICS AND TOXICITY. American Journal of Roentgenology. 1989;152:167-73.

[13] Alarifi S, Ali D, Alkahtani S, Alhader MS. Iron Oxide Nanoparticles Induce Oxidative Stress, DNA Damage, and Caspase Activation in the Human Breast Cancer Cell Line. Biological Trace Element Research. 2014;159:416-24.

[14] Klein S, Sommer A, Distel LVR, Hazemann JL, Kroner W, Neuhuber W, et al. Superparamagnetic Iron Oxide Nanoparticles as Novel X-ray Enhancer for Low-Dose Radiation Therapy. Journal of Physical Chemistry B. 2014;118:6159-66. 
[15] Voinov MA, Pagan JOS, Morrison E, Smirnova TI, Smirnov Al. Surface-Mediated Production of Hydroxyl Radicals as a Mechanism of Iron Oxide Nanoparticle Biotoxicity. Journal of the American Chemical Society. 2011;133:35-41.

[16] Lewinski N, Colvin V, Drezek R. Cytotoxicity of nanoparticles. Small. 2008;4:26-49.

[17] Auffan M, Achouak W, Rose J, Roncato M-A, Chaneac C, Waite DT, et al. Relation between the redox state of iron-based nanoparticles and their cytotoxicity toward Escherichia coli. Environmental Science \& Technology. 2008;42:6730-5.

[18] Aranda A, Sequedo L, Tolosa L, Quintas G, Burello E, Castell JV, et al. Dichloro-dihydro-fluorescein diacetate (DCFH-DA) assay: A quantitative method for oxidative stress assessment of nanoparticletreated cells. Toxicology in Vitro. 2013;27:954-63.

[19] Kam WW-Y, Banati RB. Effects of ionizing radiation on mitochondria. Free Radical Biology and Medicine. 2013;65:607-19.

[20] Yamamori T, Yasui H, Yamazumi M, Wada Y, Nakamura Y, Nakamura H, et al. Ionizing radiation induces mitochondrial reactive oxygen species production accompanied by upregulation of mitochondrial electron transport chain function and mitochondrial content under control of the cell cycle checkpoint. Free Radical Biology and Medicine. 2012;53:260-70.

[21] Azzam El, Jay-Gerin J-P, Pain D. lonizing radiation-induced metabolic oxidative stress and prolonged cell injury. Cancer Letters. 2012;327:48-60.

[22] Vives E, Brodin P, Lebleu B. A truncated HIV-1 Tat protein basic domain rapidly translocates through the plasma membrane and accumulates in the cell nucleus. Journal of Biological Chemistry. 1997;272:16010-7.

[23] Austin LA, Kang B, Yen CW, El-Sayed MA. Nuclear Targeted Silver Nanospheres Perturb the Cancer Cell Cycle Differently than Those of Nanogold. Bioconjugate Chem. 2011;22:2324-31.

[24] Wang C, Qiao L, Zhang Q, Yan H, Liu K. Enhanced cell uptake of superparamagnetic iron oxide nanoparticles through direct chemisorption of FITC-Tat-PEG(600)-b-poly(glycerol monoacrylate). International Journal of Pharmaceutics. 2012;430:372-80.

[25] Josephson L, Tung $\mathrm{CH}$, Moore A, Weissleder R. High-efficiency intracellular magnetic labeling with novel superparamagnetic-tat peptide conjugates. Bioconjugate Chem. 1999;10:186-91.

[26] Lewin M, Carlesso N, Tung CH, Tang XW, Cory D, Scadden DT, et al. Tat peptide-derivatized magnetic nanoparticles allow in vivo tracking and recovery of progenitor cells. Nat Biotechnol. 2000;18:410-4.

[27] Rao KS, Reddy MK, Horning JL, Labhasetwar V. TAT-conjugated nanoparticles for the CNS delivery of anti-HIV drugs. Biomaterials. 2008;29:4429-38.

[28] Torchilin VP. Tat peptide-mediated intracellular delivery of pharmaceutical nanocarriers. Advanced Drug Delivery Reviews. 2008;60:548-58.

[29] de la Fuente JM, Berry CC. Tat peptide as an efficient molecule to translocate gold nanoparticles into the cell nucleus. Bioconjugate Chem. 2005;16:1176-80.

[30] Oyelere AK, Chen PC, Huang X, El-Sayed IH, El-Sayed MA. Peptide-conjugated gold nanorods for nuclear targeting. Bioconjugate Chem. 2007;18:1490-7.

[31] Xu C, Xie J, Kohler N, Walsh EG, Chin YE, Sun S. Monodisperse magnetite nanoparticles coupled with nuclear localization signal peptide for cell-nucleus targeting. Chemistry-an Asian Journal. 2008;3:548-52.

[32] Yang C, Neshatian M, van Prooijen M, Chithrani DB. Cancer Nanotechnology: Enhanced Therapeutic Response Using Peptide-Modified Gold Nanoparticles. Journal of Nanoscience and Nanotechnology. 2014;14:4813-9.

[33] Terman A, Kurz T, Gustafsson B, Brunk UT. Lysosomal labilization. lubmb Life. 2006;58:531-9.

[34] Zhao M, Antunes F, Eaton JW, Brunk UT. Lysosomal enzymes promote mitochondrial oxidant production, cytochrome c release and apoptosis. European Journal of Biochemistry. 2003;270:3778-86. 
[35] Kirkegaard T, Jaattela M. Lysosomal involvement in cell death and cancer. Biochimica Et Biophysica Acta-Molecular Cell Research. 2009;1793:746-54.

[36] Pan LM, He QJ, Liu JN, Chen Y, Ma M, Zhang LL, et al. Nuclear-Targeted Drug Delivery of TAT Peptide-Conjugated Monodisperse Mesoporous Silica Nanoparticles. Journal of the American Chemical Society. 2012;134:5722-5.

[37] Palmacci S, Josephson L. Synthesis of polysaccharide covered superparamagnetic oxide colloids. United States: Advanced Magnetics, Inc.; 1993.

[38] Tucci P, Porta G, Agostini M, Dinsdale D, lavicoli I, Cain K, et al. Metabolic effects of TiO2 nanoparticles, a common component of sunscreens and cosmetics, on human keratinocytes. Cell Death \& Disease. 2013;4.

[39] Duvigneau JC, Piskernik C, Haindl S, Kloesch B, Hartl RT, Huettemann M, et al. A novel endotoxininduced pathway: upregulation of heme oxygenase 1 , accumulation of free iron, and free iron-mediated mitochondrial dysfunction. Laboratory Investigation. 2008;88:70-7.

[40] Zhou T, Yu M, Zhang B, Wang L, Wu X, Zhou H, et al. Inhibition of Cancer Cell Migration by Gold Nanorods: Molecular Mechanisms and Implications for Cancer Therapy. Advanced Functional Materials. 2014;24:6922-32.

[41] Song N, Kim AJ, Kim H-J, Jee HJ, Kim M, Yoo YH, et al. Melatonin suppresses doxorubicin-induced premature senescence of $A 549$ lung cancer cells by ameliorating mitochondrial dysfunction. Journal of Pineal Research. 2012;53:335-43.

[42] Hill BG, Benavides GA, Lancaster JR, Jr., Ballinger S, Dell'Italia L, Zhang J, et al. Integration of cellular bioenergetics with mitochondrial quality control and autophagy. Biological Chemistry. 2012;393:1485512.

[43] Grosso S, Doyen J, Parks SK, Bertero T, Paye A, Cardinaud B, et al. MiR-210 promotes a hypoxic phenotype and increases radioresistance in human lung cancer cell lines. Cell Death \& Disease. 2013;4.

[44] Domenech M, Marrero-Berrios I, Torres-Lugo M, Rinaldi C. Lysosomal Membrane Permeabilization by Targeted Magnetic Nanoparticles in Alternating Magnetic Fields. ACS Nano. 2013;7:5091-101.

[45] Kornhuber J, Henkel AW, Groemer TW, Staedtler S, Welzel O, Tripal P, et al. Lipophilic Cationic Drugs Increase the Permeability of Lysosomal Membranes in a Cell Culture System. Journal of Cellular Physiology. 2010;224:152-64.

[46] Guicciardi ME, Leist M, Gores GJ. Lysosomes in cell death. Oncogene. 2004;23:2881-90.

[47] Hervouet E, Simonnet $H$, Godinot C. Mitochondria and reactive oxygen species in renal cancer. Biochimie. 2007;89:1080-8.

[48] Chacko BK, Kramer PA, Ravi S, Benavides GA, Mitchell T, Dranka BP, et al. The Bioenergetic Health Index: a new concept in mitochondrial translational research. Clinical Science. 2014;127:367-73.

[49] Khan MI, Mohammad A, Patil G, Naqvi SAH, Chauhan LKS, Ahmad I. Induction of ROS, mitochondrial damage and autophagy in lung epithelial cancer cells by iron oxide nanoparticles. Biomaterials. 2012;33:1477-88.

[50] Cohn CA, Simon SR, Schoonen MAA. Comparison of fluorescence-based techniques for the quantification of particle-induced hydroxyl radicals. Particle and Fibre Toxicology. 2008;5.

[51] Park E-J, Umh HN, Choi D-H, Cho MH, Choi W, Kim S-W, et al. Magnetite- and maghemite-induced different toxicity in murine alveolar macrophage cells. Archives of Toxicology. 2014;88:1607-18.

[52] Ahamed M, Alhadlaq HA, Khan MAM, Akhtar MJ. Selective killing of cancer cells by iron oxide nanoparticles mediated through reactive oxygen species via p53 pathway. Journal of Nanoparticle Research. 2013;15.

[53] Cochran DB, Wattamwar PP, Wydra R, Hilt JZ, Anderson KW, Eitel RE, et al. Suppressing iron oxide nanoparticle toxicity by vascular targeted antioxidant polymer nanoparticles. Biomaterials. 2013;34:9615-22. 
[54] Ahamed M, Alhadlaq HA, Alam J, Khan M, Ali D, Alarafi S. Iron Oxide Nanoparticle-induced Oxidative Stress and Genotoxicity in Human Skin Epithelial and Lung Epithelial Cell Lines. Curr Pharm Design. 2013;19:6681-90.

[55] Ito A, Fujioka M, Yoshida T, Wakamatsu K, Ito S, Yamashita T, et al. 4-S-Cysteaminylphenol-loaded magnetite cationic liposomes for combination therapy of hyperthermia with chemotherapy against malignant melanoma. Cancer Science. 2007;98:424-30.

[56] Babincova M, Altanerova V, Altaner C, Bergemann C, Babinec P. In vitro analysis of cisplatin functionalized magnetic nanoparticles in combined cancer chemotherapy and electromagnetic hyperthermia. leee Transactions on Nanobioscience. 2008;7:15-9. 